\title{
Mapping odorant receptors in neural space
}

\author{
Thomas C Bozza \\ From 1st International Workshop on Odor Spaces \\ Hannover, Germany. 4-7 September 2013
}

The olfactory system represents chemical information as spatial and temporal activity patterns across glomeruli in the olfactory bulb. The degree to which chemical features are mapped systematically in the glomerular array has remained controversial. Using mouse genetics, we have begun to elucidate the factors influencing the organization of glomeruli in the olfactory bulb. We find that the three broad classes of olfactory receptor genes (Class I, Class II, and TAARs) are roughly organized into distinct domains of the dorsal olfactory bulb. Despite the fact that odorant receptors are involved in axon guidance, this mechanism is receptor-independent and derives from the axon guidance identities of sensory neurons in the epithelium. Consequently, the same receptor (i.e. a given response specificity) can be mapped to different bulb domains when the receptor is expressed by different cell types. Our overall results show that odorant responsiveness can be decoupled from glomerular position, and that glomerular position is not necessarily determined by stimulus specificity. In this view, the glomerular map may be shaped by the selection of receptor coding sequences (which determine receptor identity) and their corresponding promoters (which determines cell type expression) over evolutionary time. The precision of potential chemotopic maps that could form in the glomerular array is limited by the precision of this "evolutionary mapping" mechanism.

Submit your next manuscript to BioMed Central and take full advantage of:

- Convenient online submission

- Thorough peer review

- No space constraints or color figure charges

- Immediate publication on acceptance

- Inclusion in PubMed, CAS, Scopus and Google Scholar

- Research which is freely available for redistribution

Submit your manuscript at

ans ( 2014 Bozza; licensee BioMed Central Ltd. This is an Open Access article distributed under the terms of the Creative Commons Attribution License (http://creativecommons.org/licenses/by/2.0), which permits unrestricted use, distribution, and reproduction in any medium, provided the original work is properly cited. The Creative Commons Public Domain Dedication waiver (http:// creativecommons.org/publicdomain/zero/1.0/) applies to the data made available in this article, unless otherwise stated. 